\section{Five-star rating for flowable restorative}

3M Filtek Supreme Flowable Restorative has been awarded a 5-star rating by the Dental Advisor.

Evaluated by 51 dental experts and tested more than 1,000 times, the composite material received an outstanding $96 \%$ clinical rating. It was recognised, in particular, for the ergonomic design of its new dispenser that led to easy handling and user comfort. It was also praised for its excellent adaption, polish retention and wear resistance.

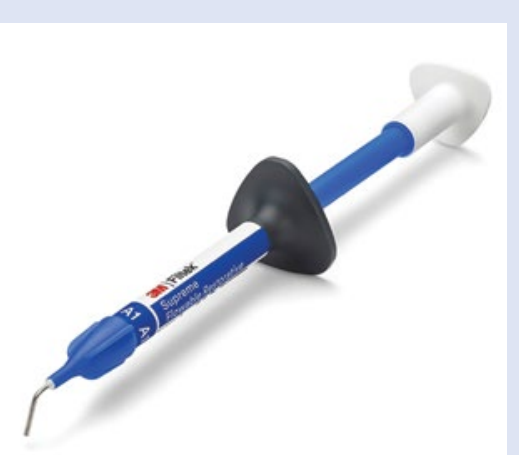

Ninety-eight percent of consultants said they would recommend Filtek Supreme Flowable Restorative from 3M to a colleague. Find out why for yourself today!

For more information, call 08705360 036 or visit www.3M.co.uk/Dental, $3 \mathrm{M}$ representatives continue to be available via video calling technologies for your convenience.

$3 \mathrm{M}$ and Filtek are trademarks of the 3M Company.

\section{Gain more flexibility with your cash flow}

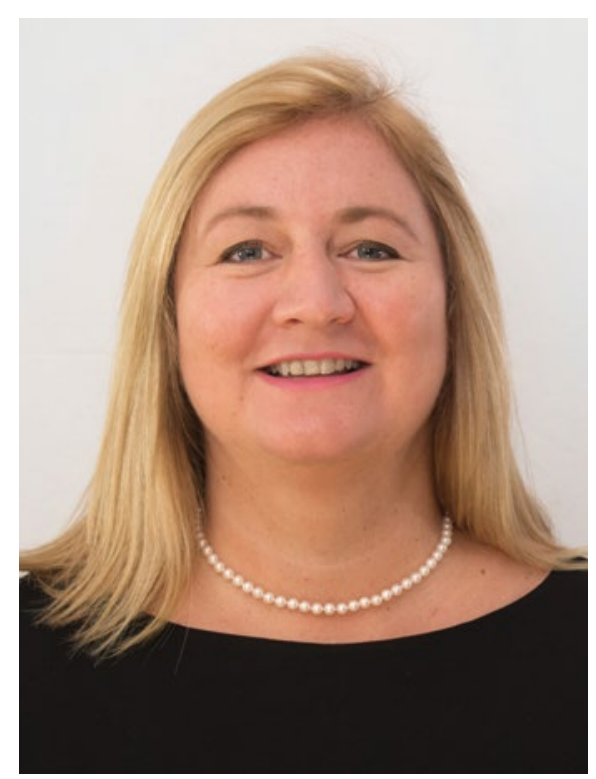

having to deal with the impact that paying out a lump sum to HMRC has on a firm's cash flow. We introduced the Braemar Finance Tax Loan to help business owners avoid any HMRC penalties and daily interest charges for late submission.

'We fund personal, business, corporation, capital gains and cross over tax demands and will consider consolidation of existing agreements. With flexible repayment terms and fixed monthly payments, the payment can be made directly to HMRC or your bank account by Faster Payment transfer.'

As part of Braemar Finance's commitment to supporting its clients through all economic cycles, it has extended the repayment term for tax loans up to 24 months for those that need extra time to repay.

Braemar Finance have been serving dentists for nearly 30 years and in that time have become experts in helping businesses in the dental sector with equipment finance and business loans, enabling them to gain more flexibility from their cash flow.

Aileen Boyle, Managing Director at Braemar Finance (pictured), explains how the company can help firms with tax: 'Every tax season brings its own challenges but fortunately there are finance options available to both individuals and businesses to help spread the cost of any tax liability. At Braemar Finance we have a product that allows professionals and business owners to take control of their cash flow through manageable monthly payments.

'We have found that "tax time" can be incredibly stressful for business owners because no-one enjoys the thought of
The application process is very simple tell Braemar Finance the amount of your tax bill and the term you would prefer and their in-house specialist underwriters will provide a quick decision. They will then tailor the tax loan to suit your circumstances with fixed payments over the agreed repayment period.

The benefits of a tax loan include:

- Control of cash flow

- Fixed monthly payments

- Repayment term up to 24 months

- Faster Payment transfer

- Protects existing bank facilities

- Quick and simple to arrange

- HMRC receive payment on time.

For more information visit www. braemarfinance.co.uk/tax or call 01563 898062 .

\title{
Exceptional support
}

Nuview prides itself on offering exceptional support to dental professionals.

To help you enhance your infection control and prevention protocols, Nuview supplies a range of advanced solutions, including the JADE Air Purification System. This features Surgically Clean Air multi-stage filtration technology, which operates quietly to effectively clean and purify indoor air.

Nuview also stocks Uvex visors that are designed to ensure comfortable, full-face protection from various contaminants. Additionally, Nuview can provide you with Zeiss Microscope Drapes and VisionGuard lenses to optimally protect your dental microscope.

For more information call Nuview on 01453 872266, email info@nuview-ltd.com, visit www.nuview.co or 'like' Nuview on Facebook.
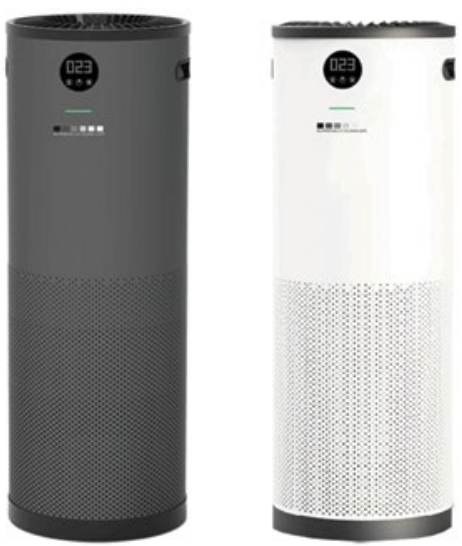